\title{
Parental Perception Towards Flu Vaccination for Asthmatic Children in Saudi Arabia
}

\author{
Alaa AlQurashi ${ }^{1}$, Hala Aljishi ${ }^{1}$, Enass Demyati ${ }^{2}$ \\ 1. Epidemiology and Public Health, King Fahad Medical City, Riyadh, SAU 2. Family Medicine, King Fahad Medical City, \\ Riyadh, SAU
}

Corresponding author: Alaa AlQurashi, alqurashi.alaa@gmail.com

\section{Abstract \\ Background}

Asthma is a major noncommunicable disease that affects around 235 million people, including children, globally. In the Kingdom of Saudi Arabia (KSA), the incidence of childhood asthma continues to increase. The Ministry of Health in Saudi Arabia has attempted to put policies in place to prevent the occurrence of asthma-related complications by encouraging parents to vaccinate their diagnosed asthmatic children with the flu vaccine. To date, however, there have been no studies investigating the use of flu vaccine among asthmatic children in KSA. Our research aims to explore the perception of parents with asthmatic children towards flu vaccination and its effect on the decision to vaccinate their children.

\section{Methods}

Our research was a cross-sectional study of 190 parents who presented with asthmatic children at King Fahad Medical City (KFMC) in Riyadh, KSA from October 2016 to April 2017. The study tools included structured and semi-structured questionnaires with demographic information, types of healthcare, and perceptions of parents towards flu vaccination. Data analysis was done using Statistical Package for the Social Sciences (SPSS; IBM, Armonk, NY).

\section{Results}

Samples were mostly Saudis (97\%), who were married (92\%), and in the age group of 21-40 years (70\%). Most of them were females (59\%). More than two-thirds of the parents had a middle school education or bachelor's degree, and more than half were employed. Parents with higher education had a higher rate of vaccination for their children, and they were more likely to believe that a non-vaccinated child is more likely to get flu. Almost $76 \%$ of parents with vaccinated children agreed that the flu vaccine could safeguard children against flu. Doctors' opinion about flu vaccination was significantly associated with the parents' decision. The multivariate regression analysis results showed that easy access to services and parents' beliefs regarding vaccination are positively associated with influenza vaccination status.

Received 10/22/2019

Review began 12/09/2019 Review ended 12/18/2019 Published 12/25/2019

\section{() Copyright 2019}

AIQurashi et al. This is an open access article distributed under the terms of the Creative Commons Attribution License CC-BY 3.0., which permits unrestricted use, distribution, and reproduction in any medium, provided the original author and source are credited.

\section{Conclusion}

Among the essential factors positively associated with the influenza vaccination status were a perception of easy access to vaccination services and the belief that non-vaccinated children are more likely to contract the flu virus. In contrast, the belief that vaccination prevents infection by the flu virus was negatively associated with vaccine uptake.

Categories: Family/General Practice, Pediatrics, Epidemiology/Public Health

Keywords: asthma, flu vaccination, children

\section{Introduction}

Asthma, a major non-communicable disease characterized by recurrent attacks of breathlessness and wheezing, affects around 235 million people globally. The World Health Organization (WHO) has reported ann estimated 383,000 asthma-related deaths in 2015, many of which occurred in low- and middle-income countries [1]. It is a common disease among children. While asthma may be triggered by numerous factors (e.g., polluted air, outdoor and indoor allergens, and stressful lifestyle), viral infection of the respiratory tract (e.g., influenza) remains the leading risk factor for childhood asthma [2]. Studies have shown that approximately $85 \%$ of asthma attacks in children are related to this viral infection, which exacerbates asthma symptoms and leads to admission to the emergency department and hospitalization $[3,4,5]$.

In the Kingdom of Saudi Arabia (KSA), the incidence of childhood asthma continues to increase [6]. The American Academy of Pediatrics and the WHO have recommended an annual administration of influenza vaccination for asthmatic children during fall and winter seasons $[7,8]$. These vaccinations are recommended as a precautionary measure to control serious asthma complications, including pneumonia [8]. Numerous 
research studies have been conducted to investigate the barriers and facilitators for vaccine uptake in the US [9]. However, despite these recommendations, a low rate of adherence to vaccination guidelines has been reported in many countries. Notably, the Middle Eastern countries account for only $3.7 \%$ of the flu vaccines administered worldwide [10].

Several studies have investigated the factors contributing to higher asthma prevalence among children $[11,12]$. In addition to poor air quality and environmental factors, viral infections are the most common triggering factor that leads to asthma in children aged 4 to 10 years [13]. The Saudi Ministry of Health has devised a management plan to control the occurrence of asthma-related complications [14]. The program focuses on raising public awareness by educating and encouraging parents to inoculate their asthmatic children with the flu vaccine. To date, however, there have been no studies investigating the details of the administration of flu vaccine among asthmatic children in KSA. Most of the current studies explore the adherence of healthcare workers to the recommendations for flu vaccination [15]. Thus, our research aims to examine the perception of parents with asthmatic children toward flu vaccination and its association with their decision to vaccinate their children in KSA.

\section{Materials And Methods}

This cross-sectional study was conducted at the King Fahad Medical City (KFMC) in Riyadh, KSA, from September 2016 to April 2017. KFMC is an academic teaching hospital with a capacity of 600 beds, catering to patients in Riyadh and the surrounding areas. We interviewed a total of 190 parents at the family medicine clinic and asthma clinic. The inclusion criteria included: 1) parents who had at least one asthmatic children aged 6 months to 15 years; 2) parents of children who were admitted to the emergency department and/or had been hospitalized during the previous 12 months; and 3) parents of children receiving medications for asthma (i.e., inhaled steroid, oral steroid, leukotriene antagonist, cromolyn/nedocromil, and salmeterol or theophylline). All clinical information was obtained from the electronic medical records of KFMC. Parents of children without a medical record in KFMC and those of children with medical conditions considered as contraindications to vaccination against the flu were excluded.

In terms of the tool we used, this study is similar to a previous study conducted in the US, which examined modifiable factors contributing to increased vaccination rates [16]. The survey tool was adopted from the Triandis model [16]. The original self-report instrument was designed to collect information regarding the facilitating conditions, behavioral habits, value of consequences of the activity, social influences (including the influence of the clinician on patients), and attitudes toward the activity [16]. This model has been used and validated in numerous settings for the investigation of health-related behaviors [17,18]. The survey tool was translated into Arabic, validated using a forward-back translation by two independent translators, and piloted on 10 participants to ensure the validity of the results. The semi-structured questionnaire included demographic and statements on knowledge and attitudes, perceived benefits, social support, adverse events observed, and perceived barriers to adherence. Each category was based on the Likert agreement scale and used to measure the respondents' agreement. All data were analyzed using the statistical package SPSS version 22.0 (IBM, Armonk, NY).

In terms of sampling, a trained research assistant approached all parents attending the family medicine clinic and asthma clinic each week from October 2016 to April 2017. Parents who agreed to participate in the study and signed the informed consent form were interviewed. The response rate was $100 \%$, and all invited participants completed the questionnaire. The sample was conveniently collected to include all eligible parents attending the flu and family clinics each week. The asthma clinic was included to limit any possible participant-selection bias of parents attending it not being aware of the availability of the flu vaccine. Recall bias regarding vaccination data was controlled by rechecking the hospital records to confirm the flu vaccination status.

In terms of data analysis, all categorical variables such as sex, educational level, and vaccination status are presented as numbers and percentages. Based on whether the cell expected frequency was $<5$, the chisquared or Fisher's exact test was used to determine significant relationships between categorical variables. Binary logistic regression was applied to determine the significant factors associated with parental perception regarding the flu vaccine. A p-value below 0.05 denoted a statistically significant difference. Ethical approval was obtained from the Institution Review Board at KFMC.

\section{Results}

A total of 190 of Saudi parents were interviewed. An overwhelming majority of them were Saudis nationals (97\%). Most of the interviewed parents were aged 20-40 years. Almost $60 \%$ of the interviewed parents were mothers. Of note, 88 parents were vaccinated (46.3\%), whereas 102 parents were not (53.7\%) (Table 1). 


\section{Cureus}

\begin{tabular}{|c|c|c|}
\hline \multirow{2}{*}{ Nationality } & Saudi & $185(97.4 \%)$ \\
\hline & Non-Saudi & $5(2.6 \%)$ \\
\hline \multirow{3}{*}{ Age } & $\leq 20$ & 14 (7.4\%) \\
\hline & $21-40$ & $133(70 \%)$ \\
\hline & $>40$ & 43 (22.6\%) \\
\hline \multirow{2}{*}{ Sex } & Male & 78 (41.1\%) \\
\hline & Female & 112 (58.9\%) \\
\hline \multirow{3}{*}{ Marital status } & Married & 174 (91.6\%) \\
\hline & Divorced & $2(1.1 \%)$ \\
\hline & Other & 14 (7.4\%) \\
\hline \multirow{4}{*}{ Educational level } & Not educated & $10(5.3 \%)$ \\
\hline & Middle education & 68 (35.8\%) \\
\hline & Bachelor & 73 (38.4\%) \\
\hline & Higher education & $39(20.5 \%)$ \\
\hline \multirow{3}{*}{ Occupation } & Employed & $100(52.6 \%)$ \\
\hline & Unemployed & 78 (41.1\%) \\
\hline & Other & $12(6.3 \%)$ \\
\hline \multirow{2}{*}{ Asthmatic children flu vaccination status } & Vaccinated & 88 (46.3\%) \\
\hline & Non-vaccinated & 102 (53.7\%) \\
\hline \multicolumn{3}{|l|}{ (b) Perceptions } \\
\hline \multirow{3}{*}{ Children with asthma should receive flu vaccination } & Agree & $173(91.1 \%)$ \\
\hline & Do not agree & $4(2.1 \%)$ \\
\hline & Do not know & $13(6.8 \%)$ \\
\hline \multirow{3}{*}{ I received a reminder from the primary care unit/hospital regarding my child's flu vaccination appointment } & Agree & $137(72.1 \%)$ \\
\hline & Do not agree & $25(13.2 \%)$ \\
\hline & Do not know & $28(14.7 \%)$ \\
\hline \multirow{3}{*}{ It is easy to reach the primary care unit/hospital to receive the flu vaccination } & Agree & 166 (87.4\%) \\
\hline & Do not agree & $14(7.4 \%)$ \\
\hline & Do not know & $10(5.3 \%)$ \\
\hline \multirow{3}{*}{ I believe that my child has to receive the flu vaccination } & Agree & 173 (91.1\%) \\
\hline & Do not agree & $8(4.2 \%)$ \\
\hline & Do not know & $9(4.7 \%)$ \\
\hline \multirow{3}{*}{ The flu vaccination may cause complications/troubles to my child } & Agree & $36(18.9 \%)$ \\
\hline & Do not agree & $122(64.2 \%)$ \\
\hline & Do not know & $32(16.8 \%)$ \\
\hline \multirow{5}{*}{ The maximum limit of flu vaccine for children per visit is } & One shot & $108(56.8 \%)$ \\
\hline & Two shots & $82(43.2 \%)$ \\
\hline & Three shots & $0(0.0 \%)$ \\
\hline & Four shots & $0(0.0 \%)$ \\
\hline & Agree & $53(27.9 \%$ \\
\hline
\end{tabular}




\section{Cureus}

I believe that my child is sick because of the flu shot

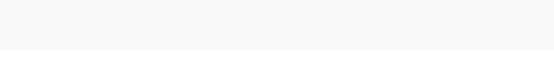

Comparing the number of times that my child got sick during last year's winter versus this winter

\section{TABLE 1: Descriptive statistics of sample characteristics and parental perceptions}

Table 2 shows the association between parental characteristics and children's vaccination status. In terms of sociodemographic parameters, the results show that a higher education level was positively associated with vaccination uptake among asthmatic children ( $\mathrm{p}$-value $=0.042$ and $<0.001$, respectively). Parents aged 21-40 years were more likely to vaccinate their children compared with those aged $>40$ years ( $\mathrm{p}$-value $=<0.001$ ). In terms of knowledge and facilitating conditions, a large number of parents with vaccinated children agreed that non-vaccinated children are more likely to contract the flu $(p$-value $=<0.001)$. Unexpectedly, parents of both vaccinated and non-vaccinated children reported that children with asthma should receive the flu vaccine $(p$-value $=0.002$ ). Moreover, they reported that their pediatrician had recommended that the children should receive the flu vaccine $(\mathrm{p}$-value $=0.016$ ), and the hospital had made the vaccine accessible to the parents ( $\mathrm{p}$-value $=0.002$ )

\begin{tabular}{|c|c|c|c|c|}
\hline Characteristic of the parents & Description & Vaccinated & $\begin{array}{l}\text { Non- } \\
\text { vaccinated }\end{array}$ & $\begin{array}{l}\text { P- } \\
\text { value }\end{array}$ \\
\hline \multirow{4}{*}{ Educational level } & Not educated & $2(2.3 \%)$ & $8(7.8 \%)$ & \multirow{4}{*}{$<0.001^{*}$} \\
\hline & $\begin{array}{l}\text { Middle } \\
\text { education }\end{array}$ & $20(22.7 \%)$ & 48 (47.1\%) & \\
\hline & Bachelor & 30 (34.1\%) & $43(42.2 \%)$ & \\
\hline & Higher education & $36(40.9 \%)$ & $3(2.9 \%)$ & \\
\hline \multirow[b]{2}{*}{ Age } & $\leq 20$ & $13(14.8 \%)$ & $1(1.0 \%)$ & \multirow[b]{2}{*}{$<0.001^{\star}$} \\
\hline & $21-40$ & 46 (52.3\%) & $87(85.3 \%)$ & \\
\hline
\end{tabular}




\section{Cureus}

\begin{tabular}{|c|c|c|c|c|}
\hline & $>40$ & $29(33 \%)$ & $14(13.7 \%)$ & \\
\hline \multirow{2}{*}{ Sex } & Male & $35(39.8 \%)$ & $43(42.2 \%)$ & \multirow{2}{*}{0.739} \\
\hline & Female & $53(60.2 \%)$ & $59(57.8 \%)$ & \\
\hline \multirow{2}{*}{ Nationality } & Saudi & $87(98.9 \%)$ & $98(96.1 \%)$ & \multirow{2}{*}{0.232} \\
\hline & Non-Saudi & $1(1.1 \%)$ & $4(3.9 \%)$ & \\
\hline \multirow{3}{*}{ Social status } & Married & $76(86.4 \%)$ & $98(96.1 \%)$ & \multirow{3}{*}{$0.042^{*}$} \\
\hline & Divorced & $1(1.1 \%)$ & $1(1.0 \%)$ & \\
\hline & Other & $11(12.5 \%)$ & $3(2.9 \%)$ & \\
\hline \multirow{3}{*}{ Occupation } & Employed & 39 (44.3\%) & $61(59.8 \%)$ & \multirow{3}{*}{0.098} \\
\hline & Unemployed & $43(48.9 \%)$ & $35(34.3 \%)$ & \\
\hline & Other & $6(6.8 \%)$ & $6(5.9 \%)$ & \\
\hline \multirow{3}{*}{ Children with asthma should receive the flu vaccination } & Agree & $77(87.5 \%)$ & $96(94.1 \%)$ & \multirow{3}{*}{0.224} \\
\hline & Do not agree & $2(2.3 \%)$ & $2(2.0 \%)$ & \\
\hline & Do not know & $9(10.2 \%)$ & $4(3.9 \%)$ & \\
\hline \multirow{3}{*}{$\begin{array}{l}\text { I received a reminder from the primary care unit/hospital regarding my child's flu } \\
\text { vaccination appointment }\end{array}$} & Agree & $64(72.7 \%)$ & $73(71.6 \%)$ & \multirow{3}{*}{0.641} \\
\hline & Do not agree & $13(14.8 \%)$ & $12(11.8 \%)$ & \\
\hline & Do not know & $11(12.5 \%)$ & $17(16.7 \%)$ & \\
\hline \multirow{3}{*}{ It is easy to reach the primary care unit/hospital to receive the flu vaccination } & Agree & $69(78.4 \%)$ & $97(95.1 \%)$ & \multirow{3}{*}{$0.002^{*}$} \\
\hline & Do not agree & $12(13.6 \%)$ & $2(2.0 \%)$ & \\
\hline & Do not know & $7(8.0 \%)$ & $3(2.9 \%)$ & \\
\hline \multirow{3}{*}{ I believe that my child has to receive the flu vaccination } & Agree & $78(88.6 \%)$ & $95(93.1 \%)$ & \multirow{3}{*}{0.533} \\
\hline & Do not agree & $5(5.7 \%)$ & $3(2.9 \%)$ & \\
\hline & Do not know & $5(5.7 \%)$ & $4(3.9 \%)$ & \\
\hline \multirow{3}{*}{ The flu vaccine may cause complications/troubles to my child } & Agree & $23(26.1 \%)$ & $13(12.7 \%)$ & \multirow{3}{*}{$<0.001^{*}$} \\
\hline & Do not agree & $42(47.7 \%)$ & $80(78.4 \%)$ & \\
\hline & Do not know & $23(26.1 \%)$ & $9(8.8 \%)$ & \\
\hline \multirow[t]{2}{*}{ The maximum limit of flu vaccine for children per visit is } & One shot & $83(94.3 \%)$ & $25(24.5 \%)$ & \multirow{2}{*}{$<0.001^{*}$} \\
\hline & Two shots & $5(5.7 \%)$ & $77(75.5 \%)$ & \\
\hline \multirow{3}{*}{ I believe that my child is sick because of the flu shot } & Agree & $29(33.0 \%)$ & $24(23.5 \%)$ & \multirow{3}{*}{0.266} \\
\hline & Do not agree & $47(53.4 \%)$ & $66(64.7 \%)$ & \\
\hline & Do not know & $12(13.6 \%)$ & $12(11.8 \%)$ & \\
\hline \multirow{3}{*}{$\begin{array}{l}\text { Comparing the number of times that my child got sick during last year's winter versus } \\
\text { this winter }\end{array}$} & $\begin{array}{l}\text { Less than last } \\
\text { winter }\end{array}$ & $20(22.7 \%)$ & 79 (77.5\%) & \multirow{3}{*}{$<0.001^{*}$} \\
\hline & $\begin{array}{l}\text { More than last } \\
\text { winter }\end{array}$ & $46(52.3 \%)$ & $4(3.9 \%)$ & \\
\hline & No difference & $22(25.0 \%)$ & $19(18.6 \%)$ & \\
\hline \multirow{3}{*}{ My child's pediatrician believes that my child should receive the flu vaccine } & Agree & $72(81.8 \%)$ & $94(92.2 \%)$ & \multirow{3}{*}{$0.016^{\star}$} \\
\hline & Do not agree & $9(10.2 \%)$ & $1(1.0 \%)$ & \\
\hline & Do not know & $7(8.0 \%)$ & $7(6.9 \%)$ & \\
\hline & Agree & $64(72.7 \%)$ & $80(78.4 \%)$ & \\
\hline My relatives believe that my child should receive the flu vaccine & Do not agree & 8 (9.1\%) & $11(10.8 \%)$ & 0.340 \\
\hline
\end{tabular}




\section{Cureus}

\begin{tabular}{|c|c|c|c|c|}
\hline & Do not know & $16(18.2 \%)$ & $11(10.8 \%)$ & \\
\hline \multirow{3}{*}{ Non-vaccinated children are more likely to contract the flu } & Agree & $63(71.6 \%)$ & $54(52.9 \%)$ & \multirow{3}{*}{$<0.001^{*}$} \\
\hline & Do not agree & $10(11.4 \%)$ & $40(39.2 \%)$ & \\
\hline & Do not know & $15(17.0 \%)$ & $8(7.8 \%)$ & \\
\hline \multirow{3}{*}{ The flue vaccination prevents infection by the flu virus } & Agree & $67(76.1 \%)$ & $90(88.2 \%)$ & \multirow{3}{*}{$0.008^{*}$} \\
\hline & Do not agree & $7(8.0 \%)$ & $5(4.9 \%)$ & \\
\hline & Do not know & $14(15.9 \%)$ & $7(6.9 \%)$ & \\
\hline \multirow{3}{*}{$\begin{array}{l}\text { I am worried about the chances of my child contracting the flu because of the flu } \\
\text { vaccine }\end{array}$} & Agree & $31(35.2 \%)$ & $14(13.7 \%)$ & \multirow{3}{*}{$0.002^{*}$} \\
\hline & Do not agree & $46(52.3 \%)$ & $73(71.6 \%)$ & \\
\hline & Do not know & 11 (12.5\%) & 15 (14.7\%) & \\
\hline
\end{tabular}

\section{TABLE 2: Association between parental characteristics and vaccination status}

*Significant p-value

In terms of attitudes, there was no significant association between attitudes and perceptions of parents toward vaccine uptake. A large number of parents $(n=78)$ agreed that a child should receive the flu vaccine, whereas only five disagreed; this belief was not reflected in the association with vaccine uptake. The attitude of parents toward vaccination (e.g., concerns regarding potential adverse effects, the required number of vaccine shots, and the comparison of flu episodes prior to and after receiving the vaccine) was significantly associated with flu vaccine uptake ( $p$-value $=<0.001$ ). In terms of social support, physicians thought that vaccination against the flu was significantly associated with parents' decision to vaccinate their children $(\mathrm{p}$-value $=0.016$ ). Parents with vaccinated children $(81.8 \%)$ and those with non-vaccinated children (92.2\%) agreed with the following statement: "my child's pediatrician believes that my child should receive the flu vaccine." In terms of perceived consequences, there was a significant association between the perceived consequences and flu vaccine uptake. The majority of parents (71\%) reported that non-vaccinated children were more likely to contract the flu ( $\mathrm{p}$-value $=<0.001$ ). Almost $76 \%$ of the parents with vaccinated children agreed that the flu vaccine prevented infection by the flu virus ( $p$-value $=0.008$ ). Only $35 \%$ of the parents were worried about contracting the flu due to the vaccine $(p$-value $=0.002)$.

Table 3 shows the independent factors associated with the uptake of the flu vaccine in children using multivariate logistic regression. Results show that the most important factors positively associated with the influenza vaccination status were easy access to vaccination services and the perception of parents that nonvaccinated children are more likely to contract the flu virus. In contrast, worrying about the chance of contracting the flu due to the vaccine and the belief that vaccination prevents infection by the flu virus were negatively associated with vaccine uptake.

\begin{tabular}{|l|c|}
\hline Survey description & OR (95\% Cl) \\
\hline It is easy to reach the primary care unit/hospital to receive the flu vaccination & $0.206(0.07-0.608)^{\star}$ \\
\hline Non-vaccinated children are more likely to contract the flu & $0.004^{\star \star}$ \\
\hline The flu vaccination prevents infection by the flu & $0.014^{\star \star}$ \\
\hline I am worried about the chances of my child contracting the flu because of the flu vaccine & $0.395(1.200-5.119)^{\star}$ \\
\hline
\end{tabular}

\section{TABLE 3: Independent factors associated with the flu vaccine uptake}

OR: odds ratio; Cl: Confidence interval;

${ }^{*}$ Reference range: do not know/do not agree

${ }^{* *}$ Significant $\mathrm{p}$-value 


\section{Discussion}

Our findings show that parents' age and education were significantly associated with the children's vaccine uptake. These findings are similar to a cross-sectional study conducted in Taiwan, where $50 \%$ of the participating parents were females with at least a middle-school education [19]. Moreover, a web-based study by Flood et al. reported that the decision to vaccinate was related to parental knowledge on the importance of childhood vaccination [20]. Parents who were aware of the flu were more likely to vaccinate their children. However, in our study, the parental level of knowledge was not positively associated with vaccine uptake in children. A possible explanation is that other factors, such as access to a healthcare service provider, may affect the decision to administer the vaccine as well.

The facilitating conditions found to be associated with the rate of vaccination among asthmatic children in KSA were consistent with the results obtained from other studies. A study by Daley et al. reported that regular reminders increased the chances of parents vaccinating their children [9]. American parents also reported that other conditions, such as availability and easy access to care, were related to the decision to vaccinate their children. Furthermore, in terms of the attitude of parents toward vaccination, a study by Chen et al. applied the health benefit model to identify differences in the rate of vaccination between Caucasian children and those of other ethnic groups. The results indicated that African- American parents were hesitant regarding flu vaccination and worried that the vaccine might cause an influenza infection [21].

Most of the Saudi parents did not agree that a vaccine could cause harm to children regardless of vaccination uptake. Further qualitative research is warranted to explore which specific factors affect the decision of Saudi parents. Also, evidence shows that social support from relatives and friends is a core factor that influences the decision of parents regarding vaccination among some American parents [21]. Allison et al. also indicated that parents who were affected by the opinions of relatives and friends regarding the positive outcomes of the vaccine were more likely to vaccinate their children [22]. However, according to our findings, Saudi parents were not influenced by their relatives. It may be argued that Saudi parents did not share their decision regarding the flu vaccine with others.

Another important social support is the one provided by healthcare providers. This type of support was significantly associated with the rate of vaccination in the present and other studies [23,24]. A study by Gaglani et al. showed that a physician's recommendation had a high impact on parents' decisions regarding vaccination against the flu [25]. Since our study did not investigate whether physicians provided recommendations, future studies should explore whether recommendations of physicians could increase the rate of vaccination in KSA.

The perceived consequences consist of two parts: the perceived benefits of the vaccine and the perceived risks linked to non-vaccination. The perceived benefits reported in the literature were associated with parental intention to vaccinate the children. A web-based study involving Chinese parents reported that parental knowledge on the potential benefits of vaccination was positively associated with the intention to vaccinate [15]. However, this association was observed among parents with healthy children, rather than asthmatic children. Another study conducted in five European countries revealed a similar association between the perceived benefits of vaccination and the high vaccine uptake [26]. However, all reported associations were noted among healthy children. Parents with asthmatic children may hesitate to vaccinate them despite being aware of the benefits. In this study, the perceived benefits were strongly associated with vaccine uptake among asthmatic children, even after adjusting for other variables in the multivariable analysis. Parents who perceived risks in this study were more likely to be favorable toward the vaccine uptake.

\section{Conclusions}

Although parents agreed with most of the positive statements of perception toward the vaccine against the flu in asthmatic children, the rate of vaccination among their children was low. This is one of the very few studies that has been conducted in the Middle East investigating the perception of parents about immunization against the flu in asthmatic children. The vaccination status was rechecked using the medical records of patients to avoid recall bias in the results of the questionnaire. However, our study was limited to participants from a single tertiary healthcare provider. Future research should conduct similar surveys in more facilities to get a broader understanding of the association between parental perceptions and vaccine uptake in KSA.

\section{Appendices}

\section{Characteristics $(n=190)$}

(a) Sample characteristics

\section{Description} N (\%)

Nationality 


\section{Cureus}

\begin{tabular}{|c|c|c|}
\hline \multirow{3}{*}{ Age } & $\leq 20$ & $14(7.4 \%)$ \\
\hline & $21-40$ & $133(70 \%)$ \\
\hline & $>40$ & $43(22.6 \%)$ \\
\hline \multirow{2}{*}{ Sex } & Male & $78(41.1 \%)$ \\
\hline & Female & $112(58.9 \%)$ \\
\hline \multirow{3}{*}{ Marital status } & Married & $174(91.6 \%)$ \\
\hline & Divorced & $2(1.1 \%)$ \\
\hline & Other & $14(7.4 \%)$ \\
\hline \multirow{4}{*}{ Educational level } & Not educated & $10(5.3 \%)$ \\
\hline & Middle education & $68(35.8 \%)$ \\
\hline & Bachelor & $73(38.4 \%)$ \\
\hline & Higher education & $39(20.5 \%)$ \\
\hline \multirow{3}{*}{ Occupation } & Employed & $100(52.6 \%)$ \\
\hline & Unemployed & $78(41.1 \%)$ \\
\hline & Other & $12(6.3 \%)$ \\
\hline \multirow{2}{*}{ Vaccination status } & Vaccinated & $88(46.3 \%)$ \\
\hline & Non-vaccinated & $102(53.7 \%)$ \\
\hline \multicolumn{3}{|l|}{ (b) Perceptions } \\
\hline \multirow{3}{*}{ Children with asthma should receive flu vaccination } & Agree & $173(91.1 \%)$ \\
\hline & Do not agree & $4(2.1 \%)$ \\
\hline & Do not know & $13(6.8 \%)$ \\
\hline \multirow{3}{*}{ I received a reminder from the primary care unit/hospital regarding my child's flu vaccination appointment } & Agree & $137(72.1 \%)$ \\
\hline & Do not agree & $25(13.2 \%)$ \\
\hline & Do not know & $28(14.7 \%)$ \\
\hline \multirow{3}{*}{ It is easy to reach the primary care unit/hospital to receive the flu vaccination } & Agree & $166(87.4 \%)$ \\
\hline & Do not agree & $14(7.4 \%)$ \\
\hline & Do not know & $10(5.3 \%)$ \\
\hline \multirow{3}{*}{ I believe that my child has to receive the flu vaccination } & Agree & $173(91.1 \%)$ \\
\hline & Do not agree & $8(4.2 \%)$ \\
\hline & Do not know & $9(4.7 \%)$ \\
\hline \multirow{3}{*}{ The flu vaccination may cause complications/troubles to my child } & Agree & $36(18.9 \%)$ \\
\hline & Do not agree & $122(64.2 \%)$ \\
\hline & Do not know & $32(16.8 \%)$ \\
\hline \multirow{4}{*}{ The maximum limit of flu vaccine for children per visit is } & One shot & $108(56.8 \%)$ \\
\hline & Two shots & $82(43.2 \%)$ \\
\hline & Three shots & $0(0.0 \%)$ \\
\hline & Four shots & $0(0.0 \%)$ \\
\hline \multirow{2}{*}{ I believe that my child is sick because of the flu shot } & Agree & $53(27.9 \%)$ \\
\hline & o not agree & $113(59.5 \%)$ \\
\hline
\end{tabular}




\section{Cureus}

\begin{tabular}{|c|c|c|}
\hline & Do not know & $24(12.6 \%)$ \\
\hline \multirow{3}{*}{ Comparing the number of times that my child got sick during last year's winter versus this winter } & Less than last winter & $99(52.1 \%)$ \\
\hline & More than last winter & $50(26.3 \%)$ \\
\hline & No difference & $41(21.6 \%)$ \\
\hline \multirow{3}{*}{ My child's pediatrician believes that my child should receive the flu vaccine } & Agree & $166(87.4 \%)$ \\
\hline & Do not agree & $10(5.3 \%)$ \\
\hline & Do not know & $14(7.4 \%)$ \\
\hline \multirow{3}{*}{ My relatives believe that my child should receive the flu vaccine } & Agree & $144(75.8 \%)$ \\
\hline & Do not agree & $19(10.0 \%)$ \\
\hline & Do not know & $27(14.2 \%)$ \\
\hline \multirow{3}{*}{ Non-vaccinated children are more likely to contract the flu } & Agree & $117(61.6 \%)$ \\
\hline & Do not agree & $50(26.3 \%)$ \\
\hline & Do not know & $23(12.1 \%)$ \\
\hline \multirow{3}{*}{ The flu vaccination prevents infection by the flu virus } & Agree & $157(82.6 \%)$ \\
\hline & Do not agree & $12(6.3 \%)$ \\
\hline & Do not know & $21(11.1 \%)$ \\
\hline \multirow{3}{*}{ I am worried about the chances of my child contracting the flu because of the flu vaccine } & Agree & $45(23.7 \%)$ \\
\hline & Do not agree & $119(62.6 \%)$ \\
\hline & Do not know & 26 (13.7\%) \\
\hline
\end{tabular}

\section{TABLE 4: Descriptive statistics of sample characteristics and parental perceptions}

$\mathrm{N}$ : number of respondents

\begin{tabular}{|c|c|c|c|c|}
\hline Characteristic & Description & Vaccinated & $\begin{array}{l}\text { Non- } \\
\text { vaccinated }\end{array}$ & $\begin{array}{l}\text { P- } \\
\text { value }\end{array}$ \\
\hline \multirow{4}{*}{ Educational level } & Not educated & $2(2.3 \%)$ & $8(7.8 \%)$ & \multirow{4}{*}{$<0.001^{\star}$} \\
\hline & $\begin{array}{l}\text { Middle } \\
\text { education }\end{array}$ & $20(22.7 \%)$ & $48(47.1 \%)$ & \\
\hline & Bachelor & 30 (34.1\%) & $43(42.2 \%)$ & \\
\hline & Higher education & $36(40.9 \%)$ & $3(2.9 \%)$ & \\
\hline \multirow{3}{*}{ Age } & $\leq 20$ & $13(14.8 \%)$ & $1(1.0 \%)$ & \multirow{3}{*}{$<0.001$} \\
\hline & $21-40$ & 46 (52.3\%) & 87 (85.3\%) & \\
\hline & $>40$ & $29(33 \%)$ & $14(13.7 \%)$ & \\
\hline \multirow{2}{*}{ Sex } & Male & $35(39.8 \%)$ & $43(42.2 \%)$ & \multirow{2}{*}{0.739} \\
\hline & Female & $53(60.2 \%)$ & $59(57.8 \%)$ & \\
\hline \multirow{2}{*}{ Natıonality } & Saudı & $87(98.9 \%)$ & $98(96.1 \%)$ & \multirow{2}{*}{0.232} \\
\hline & Non-Saudi & $1(1.1 \%)$ & $4(3.9 \%)$ & \\
\hline \multirow{3}{*}{ Social status } & Married & $76(86.4 \%)$ & 98 (96.1\%) & \multirow{3}{*}{$0.042^{\star}$} \\
\hline & Divorced & $1(1.1 \%)$ & $1(1.0 \%)$ & \\
\hline & Other & $11(12.5 \%)$ & $3(2.9 \%)$ & \\
\hline
\end{tabular}




\section{Cureus}

\begin{tabular}{|c|c|c|c|c|}
\hline \multirow{3}{*}{ Occupation } & Employed & $39(44.3 \%)$ & $61(59.8 \%)$ & \multirow{3}{*}{0.098} \\
\hline & Unemployed & $43(48.9 \%)$ & 35 (34.3\%) & \\
\hline & Other & $6(6.8 \%)$ & $6(5.9 \%)$ & \\
\hline \multirow{3}{*}{ Children with asthma should receive flu vaccination } & Agree & $77(87.5 \%)$ & $96(94.1 \%)$ & \multirow{3}{*}{0.224} \\
\hline & Do not agree & $2(2.3 \%)$ & $2(2.0 \%)$ & \\
\hline & Do not know & $9(10.2 \%)$ & $4(3.9 \%)$ & \\
\hline \multirow{3}{*}{$\begin{array}{l}\text { Treceived a reminder from the primary care unit/hospital regarding my child's flu } \\
\text { vaccination appointment }\end{array}$} & Agree & $64(72.7 \%)$ & $73(71.6 \%)$ & \multirow{3}{*}{0.641} \\
\hline & Do not agree & $13(14.8 \%)$ & $12(11.8 \%)$ & \\
\hline & Do not know & $11(12.5 \%)$ & $17(16.7 \%)$ & \\
\hline \multirow{3}{*}{ It is easy to reach the primary care unit/hospital to receive the flu vaccination } & Agree & 69 (78.4\%) & 97 (95.1\%) & \multirow{3}{*}{$0.002^{\star}$} \\
\hline & Do not agree & $12(13.6 \%)$ & $2(2.0 \%)$ & \\
\hline & Do not know & $7(8.0 \%)$ & $3(2.9 \%)$ & \\
\hline \multirow{3}{*}{ I believe that my child has to receive the flu vaccination } & Agree & $78(88.6 \%)$ & 95 (93.1\%) & \multirow{3}{*}{0.533} \\
\hline & Do not agree & $5(5.7 \%)$ & $3(2.9 \%)$ & \\
\hline & Do not know & $5(5.7 \%)$ & $4(3.9 \%)$ & \\
\hline \multirow{3}{*}{ The flu vaccine may cause complications/troubles to my child } & Agree & $23(26.1 \%)$ & $13(12.7 \%)$ & \multirow{3}{*}{$<0.001^{*}$} \\
\hline & Do not agree & $42(47.7 \%)$ & $80(78.4 \%)$ & \\
\hline & Do not know & $23(26.1 \%)$ & $9(8.8 \%)$ & \\
\hline \multirow[t]{2}{*}{ The maximum limit of flu vaccine for children per visit is } & One shot & $83(94.3 \%)$ & $25(24.5 \%)$ & \multirow{2}{*}{$<0.001^{\star}$} \\
\hline & Two shots & $5(5.7 \%)$ & $77(75.5 \%)$ & \\
\hline \multirow{3}{*}{ I believe that my child is sick because of the flu shot } & Agree & $29(33.0 \%)$ & $24(23.5 \%)$ & \multirow{3}{*}{0.266} \\
\hline & Do not agree & $47(53.4 \%)$ & $66(64.7 \%)$ & \\
\hline & Do not know & $12(13.6 \%)$ & $12(11.8 \%)$ & \\
\hline \multirow{3}{*}{$\begin{array}{l}\text { Comparing the number of times that my child got sick during last year's winter versus } \\
\text { this winter }\end{array}$} & $\begin{array}{l}\text { Less than last } \\
\text { winter }\end{array}$ & $20(22.7 \%)$ & 79 (77.5\%) & \multirow{3}{*}{$<0.001^{*}$} \\
\hline & $\begin{array}{l}\text { More than last } \\
\text { winter }\end{array}$ & $46(52.3 \%)$ & $4(3.9 \%)$ & \\
\hline & No difference & $22(25.0 \%)$ & $19(18.6 \%)$ & \\
\hline \multirow{3}{*}{ My child's pediatrician believes that my child should receive the flu vaccine } & Agree & $72(81.8 \%)$ & $94(92.2 \%)$ & \multirow{3}{*}{$0.016^{\star}$} \\
\hline & Do not agree & $9(10.2 \%)$ & $1(1.0 \%)$ & \\
\hline & Do not know & $7(8.0 \%)$ & $7(6.9 \%)$ & \\
\hline \multirow{3}{*}{ My relatives believe that my child should receive the flu vaccine } & Agree & $64(72.7 \%)$ & $80(78.4 \%)$ & \multirow{3}{*}{0.340} \\
\hline & Do not agree & $8(9.1 \%)$ & $11(10.8 \%)$ & \\
\hline & Do not know & $16(18.2 \%)$ & $11(10.8 \%)$ & \\
\hline \multirow{3}{*}{ Non-vaccinated children are more likely to contract the flu } & Agree & $63(71.6 \%)$ & $54(52.9 \%)$ & \multirow{3}{*}{$<0.001^{*}$} \\
\hline & Do not agree & $10(11.4 \%)$ & $40(39.2 \%)$ & \\
\hline & Do not know & $15(17.0 \%)$ & $8(7.8 \%)$ & \\
\hline \multirow{3}{*}{ The flue vaccination prevents infection by the flu virus } & Agree & $67(76.1 \%)$ & $90(88.2 \%)$ & \multirow{3}{*}{$0.008^{*}$} \\
\hline & Do not agree & $7(8.0 \%)$ & $5(4.9 \%)$ & \\
\hline & Do not know & 14 (15.9\%) & $7(6.9 \%)$ & \\
\hline
\end{tabular}




\section{Cureus}

I am worried about the chances of my child contracting the flu because of the flu

vaccine

$\begin{array}{llll}\text { Agree } & 31(35.2 \%) & 14(13.7 \%) & \\ \text { Do not agree } & 46(52.3 \%) & 73(71.6 \%) & 0.002^{\star} \\ \text { Do not know } & 11(12.5 \%) & 15(14.7 \%) & \end{array}$

\section{TABLE 5: Association between parental characteristics and vaccination status}

*Significant p-value

\begin{tabular}{|c|c|c|}
\hline Survey description & OR (95\% Cl) & P-value \\
\hline It is easy to reach the primary care unit/hospital to receive the flu vaccination & $0.206(0.07-0.608)^{\star}$ & ${ }^{*} 0.004^{\star *}$ \\
\hline Non-vaccinated children are more likely to contract the flu & $2.479(1.200-5.119)^{\star}$ & ${ }^{*} 0.014^{\star *}$ \\
\hline The flu vaccination prevents infection by the flu & $0.395(0.157-0.992)^{\star}$ & ${ }^{*} 0.048^{\star \star}$ \\
\hline I am worried about the chances of my child contracting the flu because of the flu vaccine & $2.913(1.367-6.208)^{\star}$ & ${ }^{\star} 0.006^{\star \star}$ \\
\hline \multicolumn{3}{|c|}{ TABLE 6: Independent factors associated with the flu vaccine uptake } \\
\hline \multicolumn{3}{|l|}{ OR: odds ratio; Cl: Confidence interval; } \\
\hline \multicolumn{3}{|l|}{ *Reference range: do not know/do not agree } \\
\hline **Significant $\mathrm{p}$-value & & \\
\hline
\end{tabular}

\section{Additional Information \\ Disclosures}

Human subjects: Consent was obtained by all participants in this study. Institutional Review Board at King Fahad Medical City issued approval FWA00018774. The study has been reviewed and approved by the Institutional Review Board at King Fahad Medical City, KSA. Animal subjects: All authors have confirmed that this study did not involve animal subjects or tissue. Conflicts of interest: In compliance with the ICMJE uniform disclosure form, all authors declare the following: Payment/services info: All authors have declared that no financial support was received from any organization for the submitted work. Financial relationships: All authors have declared that they have no financial relationships at present or within the previous three years with any organizations that might have an interest in the submitted work. Other relationships: All authors have declared that there are no other relationships or activities that could appear to have influenced the submitted work.

\section{References}

1. Asthma - key facts . (2017). Accessed: December 23, 2019: https://www.who.int/news-room/factsheets/detail/asthma.

2. Minor TE, Baker JW, Dick EC, DeMeo AN, Ouellette JJ, Cohen M, Reed CE: Greater frequency of viral respiratory infections in asthmatic children as compared with their nonasthmatic siblings. J Pediat. 1974, 85:472-7. 10.1016/S0022-3476(74)80447-6

3. Johnston SL, Pattemore PK, Sanderson G, et.al: The relationship between upper respiratory infections and hospital admissions for asthma: a time-trend analysis. Am J Respir Crit Care Med. 1996, 154:654-60. 10.1164/ajrccm.154.3.8810601

4. Glezen WP: Serious morbidity and mortality associated with influenza epidemics . Epidemiol Rev. 1982, 4:25-44. 10.1093/oxfordjournals.epirev.a036250

5. Harper SA, Fukuda K, Uyeki TM, Cox NJ, Bridges CB: Prevention and control of influenza: recommendations of the Advisory Committee on Immunization Practices (ACIP). MMWR Recomm Rep. 2005, 54:1-41.

6. Al Frayh AR, Shakoor Z, Gad El Rab MO, Hasnain SM: Increased prevalence of asthma in Saudi Arabia. Ann Allergy Asthma Immunol. 2001, 86:292-6. 10.1016/s1081-1206(10)63301-7

7. Global initiative for asthma . (2011). Accessed: December 21, 2016: http://www.ginasthma.org/.

8. Robinson CL, Bernstein H, Romero JR, Szilagyi P: Advisory Committee on Immunization Practices Recommended Immunization Schedule for Children and Adolescents Aged 18 Years or Younger - United States, 2019. MMWR Morb Mortal Wkly Rep. 2019, 68:112-4. 10.15585/mmwr.mm6805a4

9. Daley MF, Crane LA, Chandramouli V, et al.: Influenza among healthy young children: changes in parental attitudes and predictors of immunization during the 2003 to 2004 influenza season. Pediatrics. 2006, 117:e268-77. 10.1542/peds.2005-1752 
10. Palache A, Oriol-Mathieu V, Abelin A, Music T; Influenza Vaccine Supply task force (IFPMA IVS): Seasonal influenza vaccine dose distribution in 157 countries (2004-2011). Vaccine. 2014, 32:6369-76. 10.1016/j.vaccine.2014.07.012

11. Hamam F, Eldalo A, Albarraq A, et.al : The prevalence of asthma and its related risk factors among the children in Taif area, Kingdom of Saudi Arabia. Saudi J Health Sci. 2015, 4:179-84. 10.4103/22780521.171436

12. Braun-Fahrländer C: Environmental exposure to endotoxin and other microbial products and the decreased risk of childhood atopy: evaluating developments since April 2002. Curr Opin Allergy Clin Immunol. 2003, 3:325-9. 10.1097/00130832-200310000-00001

13. Seasonal influenza vaccination. (2014). Accessed: December 22, 2019: https://www.moh.gov.sa/en/Flu/Pages/Prevention.aspx.

14. Rehmani R, Memon JI: Knowledge, attitudes and beliefs regarding influenza vaccination among healthcare workers in a Saudi hospital. Vaccine. 2010, 28:4283-7. 10.1016/j.vaccine.2010.04.031

15. Valois P, Desharnais R, Godin G: A comparison of the Fishbein and Ajzen and the Triandis attitudinal models for the prediction of exercise intention and behavior. J Behav Med. 1988, 11:459-72. 10.1007/BF00844839

16. Liao Q, Cowling BJ, Lam WW, Fielding R: Factors affecting intention to receive and self-reported receipt of 2009 pandemic (H1N1) vaccine in Hong Kong: a longitudinal study. PLoS One. 2011, 6:e17713. Accessed: December 22, 2019: https://www.ncbi.nlm.nih.gov/pubmed/21412418. 10.1371/journal.pone.0017713

17. Chisolm SS, Taylor SL, Gryzwacz JG, O'Neill JL, Balkrishnan RR, Feldman SR: Health behaviour models: a framework for studying adherence in children with atopic dermatitis. Clin Exp Dermatol. 2010, 35:228-32. 10.1111/j.1365-2230.2009.03741.x

18. Lin CJ, Nowalk MP, Zimmerman RK, Ko FS, Zoffel L, Hoberman A, Kearney DH: Beliefs and attitudes about influenza immunization among parents of children with chronic medical conditions over a two-year period. J Urban Health. 2006, 83:874-83. 10.1007/s11524-006-9084-Z

19. Chen MF, Wang RH, Schneider JK, Tsai CT, Jiang DD, Hung MN, Lin LJ: Using the Health Belief Model to understand caregiver factors influencing childhood influenza vaccinations. J Community Health Nurs. 2011, 28:29-40. 10.1080/07370016.2011.539087

20. Flood EM, Rousculp MD, Ryan KJ, et. al: Parents' decision-making regarding vaccinating their children against influenza: a web-based survey. Clin Ther. 2010, 32:1448-67. 10.1016/j.clinthera.2010.06.020

21. Chen JY, Fox SA, Cantrell CH, Stockdale SE, Kagawa-Singer M: Health disparities and prevention: racial/ethnic barriers to flu vaccinations. J Community Health. 2007, 32:5-20. 10.1007/s10900-006-9031-7

22. Allison MA, Reyes M, Young P, Calame L, Sheng X, Weng HY, Byington CL: Parental attitudes about influenza immunization and school-based immunization for school-aged children. Pediatr Infect Dis J. 2010, 29:751-5. 10.1097/INF.0b013e3181d8562c

23. Daley MF, Crane LA, Chandramouli V, et. al : Misperceptions about influenza vaccination among parents of healthy young children. Clin Pediatr (Phila). 2007, 46:408-17. 10.1177/0009922806298647

24. Szilagyi PG, Rodewald LE, Savageau J, Yoos L, Doane C: Improving influenza vaccination rates in children with asthma: a test of a computerized reminder system and an analysis of factors predicting vaccination compliance. Pediatrics. 1992, 90:871-5.

25. Gaglani M, Riggs M, Kamenicky C, Glezen WP: A computerized reminder strategy is effective for annual influenza immunization of children with asthma or reactive airway disease. Pediatr Infect Dis J. 2001, 20:1155-60. 10.1097/00006454-200112000-00012

26. Müller D, Szucs TD: Influenza vaccination coverage rates in 5 European countries: a population-based cross-sectional analysis of the seasons 02/03, 03/04 and 04/05. Infection. 2007, 35:308-19. 10.1007/s15010007-6218-5 